\title{
Molar incisor hypomineralization: an aesthetic conservative restorative approach
}

\author{
Hipomineralização molar-incisivo: uma abordagem restauradora estética conservadora
}

Manoelito Ferreira SILVA-JUNIOR'

Rahyza Inácio Freire de ASSIS²

Flávia Bittencourt PAZINATTO3

\begin{abstract}
The aim this study is to present a clinical case of conservative aesthetic restorative treatment of teeth 11 and 21 in a patient diagnosed with molar incisor hypomineralization. An 18-year-old female patient came to the Outpatient Restorative Dentistry Clinic at the Federal University of Espirito Santo, complaining mainly of not feeling comfortable with a color change in her anterior teeth. Molar incisor hypomineralization was diagnosed in molars and incisors and the negative psychosocial implications for the aesthetics involved were noticed. Due to factors such as age, financial viability, technical facility and low degree of severity, we opted for maximum preservation of the healthy tooth structure, through minimal surgical intervention to remove the irregular enamel only and subsequently restore the teeth involved (11 and 21) with resin composite. For the patient, this conservative procedure restored function and aesthetics, and thereby improved her emotional and social behavior. Conservative restorations can provide real solutions, especially in cases of molar incisor hypomineralization in anterior teeth where the patient's psychological state should always be considered. An appropriate assessment of the dental substrate and a careful restorative technique are necessary for success in terms of aesthetics and function and can quickly promote the patient's well-being.
\end{abstract}

Indexing terms: Amelogenesis. Dental enamel. Esthetics dental.

\section{RESUMO}

O objetivo do trabalho é apresentar um caso clínico de tratamento restaurador estético conservador de dentes anteriores (11 e 21 ) em paciente com diagnóstico de hipomineralização-molar incisivo. A paciente do sexo feminino, 18 anos, procurou o ambulatório de Odontologia Restauradora Clínica da Universidade Federal do Espírito Santo, com queixa principal de incômodo com a alteração de cor dos dentes anteriores. Houve o diagnóstico de hipomineralização-molar incisivo em dentes molares e incisvos, percebendo-se uma implicação psicossocial negativa pela estética envolvida. Devido aos fatores idade, viabilidade financeira, facilidade técnica e baixo grau de severidade da lesão, optou-se por privilegiar uma maior preservação possível de estrutura dentária sadia, sendo realizada mínima intervenção operatória, removendo-se somente o esmalte irregular com subsequente restauração com resina composta nos elementos envolvidos (11 e 21). Este procedimento restaurador conservador foi capaz de devolver à paciente função e estética, melhorando seu comportamento emocional e social. As restaurações estéticas conservadoras podem ser altamente resolutivas, principalmente em casos de hipomineralização-molar incisivo em dentes anteriores, onde o fator psicológico do paciente deve sempre ser considerado. Uma avaliação adequada do substrato dentário e criteriosa técnica restauradora são necessárias para o sucesso no âmbito estético-funcional, sendo capaz de restabelecer rapidamente o bem-estar do paciente.

Termos de indexação: Amelogênese. Esmalte dentário. Estética dentária.

\section{INTRODUCTION}

Developmental disturbances of tooth enamel, such as hypomineralization and hypoplasia, are structural anomalies which can affect both deciduous and permanent dentition'. Hypomineralization is a qualitative defect of dental tissues when clinically there is an abnormality in translucency, with smooth surfaced areas of irregular enamel thickness varying from white or cream to brown or yellow. Hypoplasia is a quantitative defect of the enamel, where there is partial or total loss ${ }^{2-3}$.

The etiology of these enamel changes includes causes of hereditary origin, such as imperfect amelogenesis, defects brought about by known causes, such as fluorosis or Turner's tooth and idiopathic enamel

\footnotetext{
${ }^{1}$ Universidade Estadual de Campinas, Faculdade de Odontologia, Programa de Pós-Graduação em em Odontologia, área de concentração Saúde Coletiva. Piracicaba, SP, Brasil.

${ }^{2}$ Universidade Estadual de Campinas, Faculdade de Odontologia, Programa de Pós-Graduação em Clínica Odontológica, área de concentração Periodontia. Piracicaba, SP, Brasil.

3 Universidade Federal do Espírito Santo, Departamento de Prótese Dentária. Av. Marechal Campos, 1468, Maruípe, 29040-090, Vitória, ES, Brasil. Correspondência para / Correspondence to: FB PAZINATTO.E-mail : <flaviabpazinatto@yahoo.com.br>.
} 
defects of unknown etiology, such as molar incisor hypomineralization $(\mathrm{MIH})^{4}$.

Molar incisor hypomineralization is defined as a systemic alteration which affects molars and usually the incisors $^{5}$. Its clinical aspects are different from those of fluorosis and imperfect amelogenesis as the enamel changes are not similar to those of counterpart teeth, and in addition there is no family pattern as in imperfect amelogenesis ${ }^{6}$. Like other enamel changes, it involves aesthetic impairment due to the opacity of the enamel. It also entails painful sensitivity ${ }^{7-8}$, and because of irregularities in the lesion contours, there is a greater accumulation of biofilm, and therefore, a higher prevalence of caries-10.

$\mathrm{MIH}$ severity ranges from mild - when there are demarcated opacities without any enamel fracture and occasional sensitivity to external stimuli - to severe, when there are demarcated opacities with fractures, caries and spontaneous or persistent hypersensitivity which affects dental function ${ }^{11}$.

Besides the functional problems brought on by the structural involvement of the enamel, there are also behavioral and psychological consequences for patients, such as loss of self-confidence and self-esteem which lead to shyness or withdrawal ${ }^{10,12}$. This is more and more due to the importance of aesthetics for personal behavior and society, which influences people's lives ${ }^{12}$. Therefore, clinical dental problems have functional and psychological consequences for patients and need to be considered by professionals.

Thus, a careful anamnesis and a detailed clinical and radiographic examination are vital for the diagnosis and drafting of a treatment plan suited to each of these alterations ${ }^{7}$. In the case of patients diagnosed with $\mathrm{MIH}$, different treatments, ranging from prevention to restoration and tooth extraction as a last resort, can be undertaken. The decision regarding which treatment to undertake is complex and depends on several factors, such as the degree of severity of the enamel defect, the patient's age, social level and expectations ${ }^{13}$.

Minimally invasive restorative dentistry is a good indication and produces solid results in many $\mathrm{MIH}$ cases. It aims at preserving as much dental structure as possible and, with the evolution of dental restorative and adhesive materials, it makes the use of functional and aesthetic techniques viable and provides conservative treatment in teeth affected by morphological changes to the enamel ${ }^{10,14-15}$.
Against such a background, the aim of this study is to present a clinical case involving an aesthetic and conservative restoration approach to anterior teeth with molar incisor hypomineralization in a patient with low self-esteem.

\section{CASE REPORT}

A brown skinned, 18-year-old female patient from the municipality of Vila Velha, Espírito Santo, came to the III Outpatient Division of the Federal University of Espírito Santo (Ufes) for service under the subject of Restorative Clinical Dentistry. Her main complaint was an aesthetic discomfort because of a color change in two upper central incisors.

The anamnesis presented no family history of changes in dental enamel. On physical examination, the patient presented good oral health conditions, although aesthetically she was affected by the abnormality in the upper and lower incisors, and all first molars. After the clinical examination, a diagnosis of molar incisor hypomineralization was reached.

In planning for the case, the following factors were considered: degree of severity of lesion, patient age, financial viability and technical facility. The treatment plan favored a conservative restorative approach, with maximum preservation of the healthy tooth structure. A minimum surgical intervention was performed on teeth 11 and 21 during which only the irregular enamel affected was removed and subsequent restoration with composite resin undertaken. For the first lower molars (36 and 46), also affected, restorations of a temporary nature were carried out in composite resin on the occlusal and a restorative rehabilitation treatment, with full crowns, was planned. The decision to restore the molar teeth at this early stage was to preserve the vertical occlusal dimension and make the restorative treatment of the upper central incisors possible. The direct restorative technique with composite resin stratification was used. After selecting the color and totally isolating the area, diamond burs were used to remove as little as possible of the affected enamel. Then acid etching was done and the conventional 2 step adhesive system (Prime \& Bond 2.1, Dentsply) was applied, according to the manufacturer's instructions. Afterwards, a small increment of microhybrid composite (Z100 UD, 3M ESPE) was placed in the bottom of the cavity, and the enameled region was restored with microparticulate composite resin (Durafill enamel B1, Heraeus-Kulzer). 

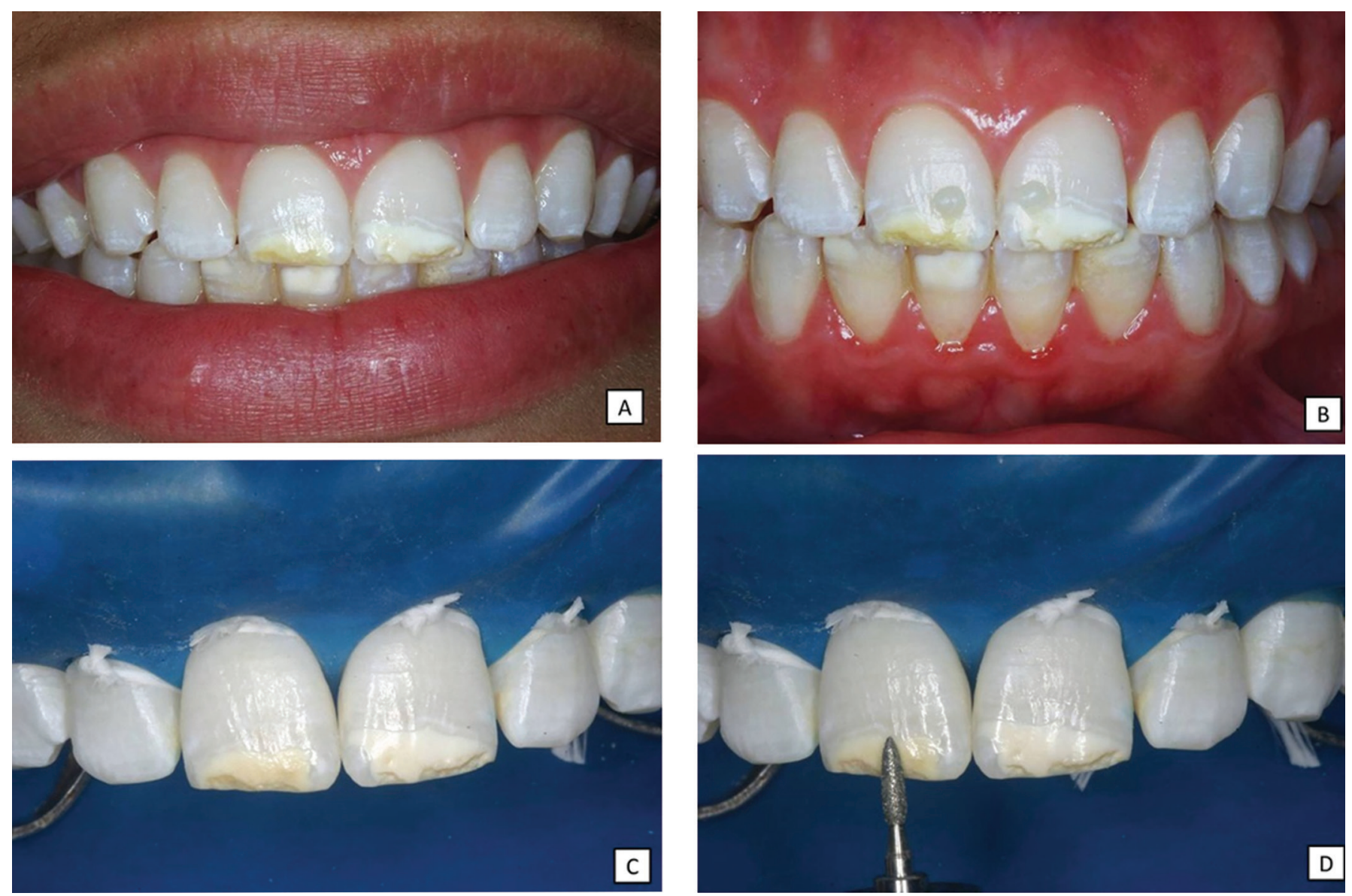

Figure 1. Clinical steps in conservative restorative treatment. A) Frontline smiling photo with morphological features of teeth 11 and 21 . B) Color selection. C) Total isolation anchored with dental floss ligature. D. Removal of the area affected by MIH with a diamond bur at high speed under constant irrigation.

\section{DISCUSSION}

In cases of $\mathrm{MIH}$, restorative intervention in anterior teeth is primarily intended to restore dental anatomy, function, occlusion and smile harmony, and thereby give the patient back their self-esteem and promote psychological and social benefits ${ }^{10,16}$.

Conservative aesthetic restorative procedures in tooth structure are only possible thanks to the development of adhesive systems. The high levels of adhesion to the enamel obtained with etching application of the adhesive system and the technological advances of composite resins mean that direct restorations with excellent retention, aesthetics and at low cost can be undertaken ${ }^{17}$. Furthermore, direct restorations present technical facility which can give the patient aesthetic and functional satisfaction, as long as the professional has the knowledge, confidence and aesthetic sensibility to do so.

There is great disagreement as to the adhesion of restorative materials in regions affected by changes in the structural components of the enamel. Some studies have shown no difference in terms of adhesion ${ }^{16}$. However, a systematic review showed that the total extraction of the affected tissue removes a large amount of tooth structure and therefore increases bond resistance, while less invasive approaches increase the risk of fracture in the margins ${ }^{13}$. In this regard, the professional should be prepared to weigh these factors when choosing the treatment.

In this case study, the quantity of hipomineralized tissue was small; the affected enamel was completely removed, especially on the margins of the cavity, before restoring with composite. Thus, adhesion occurred in healthy adjacent enamel, in suitable conditions and with a favorable prognosis. Composite resin is the restorative material of choice for treating teeth with mild or moderate $\mathrm{MlH}$, even in molars ${ }^{13}$, since it is successful in the long term in permanent teeth ${ }^{16}$. In severe cases involving 

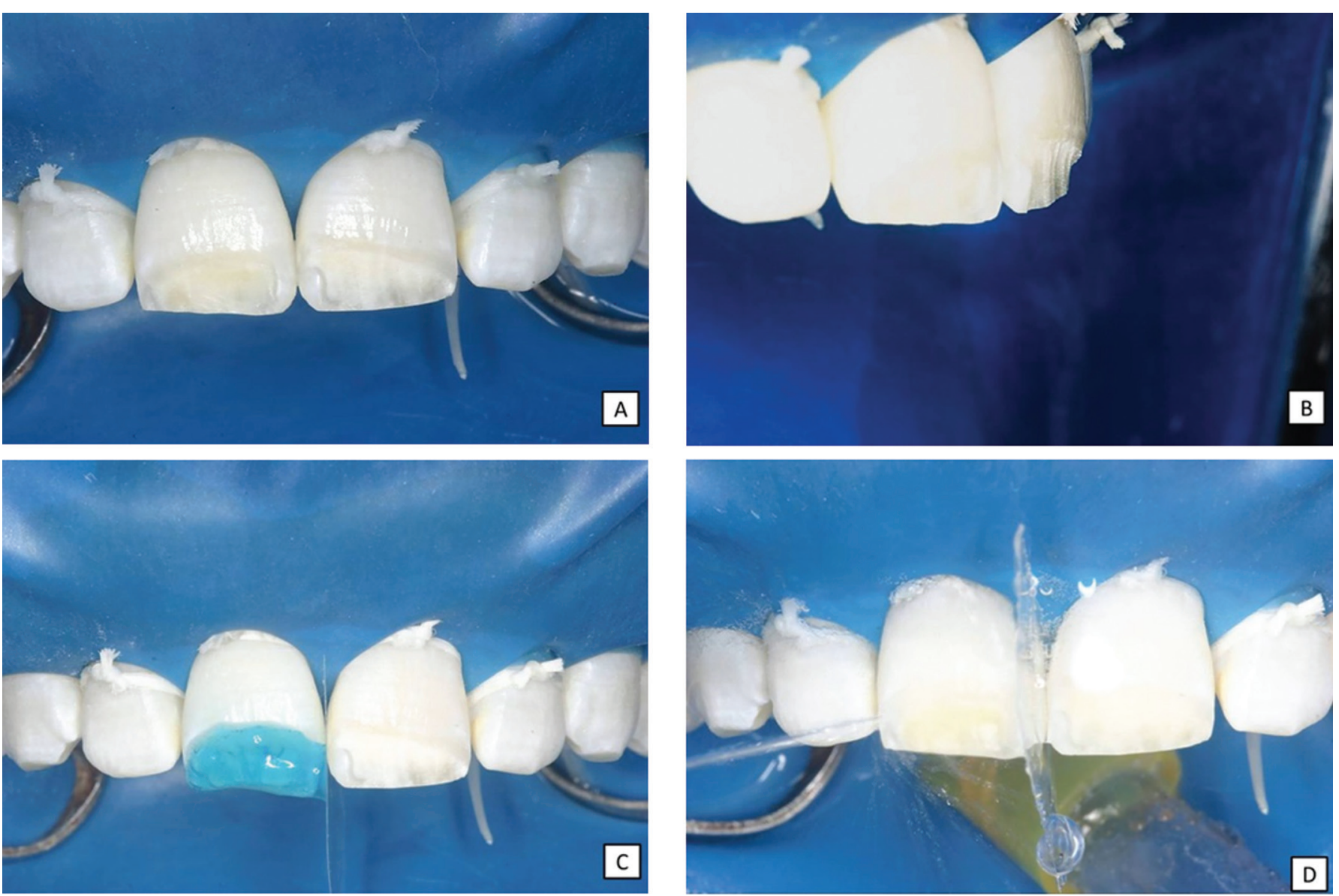

Figure 2. A) Observe the conservative removal of enamel with $\mathrm{MIH}$. B) Lateral photography to show the amount of enamel removed. C) Etching with $37 \%$ phosphoric acid for 30 seconds. D) Washing of the etched area for 1 minute.

young patients, treatment with restorative composite resin could also be used as a temporary treatment so that a permanent prosthetic approach with single-unit crowns can be performed later ${ }^{13}$.

In this clinical case, even though it was known that there were certain limitations to an approach using the minimally invasive restorative technique, the costbenefit of the biological and financial aspects were weighed, which made this direct restoration procedure possible and immediate. The healthy tooth tissue was preserved as there was minimal damage even in the region of enamel affected by $\mathrm{MIH}$. Thus, preserving the remaining tooth structure means that the direct restorative technique is the procedure of choice for the treatment of young patients, because in the future the composite resin restorations might need to be repaired in view of the longevity limitations proper to the restorative materials used, adhesive systems and composite resins. In addition, because of the reversibility of the treatment, there is a possibility of other future approaches, with indirect restorations, without affecting the resistance of the remaining tooth structure ${ }^{17}$. Thus, preservation is crucial to long term success, as it serves to monitor the treatment that was undertaken.

It is worth noting that the use of resin composites for the aesthetic rehabilitation of the anterior teeth meant that the polychromatic appearance of the natural tooth and the stratification characteristics could be reproduced, within the limitations of this particular clinical case. The end aesthetic result led to a change in the patient's psychosocial behavior. Her improved self-esteem was reflected in her broad happy smile 10,16 .

\section{CONCLUSION}

In this clinical case of molar incisor hypomineralization, a conservative aesthetic intervention, through direct restoration with composite resin presented a satisfactory result and solution, considering the low degree of severity of the area affected, age, psychological 

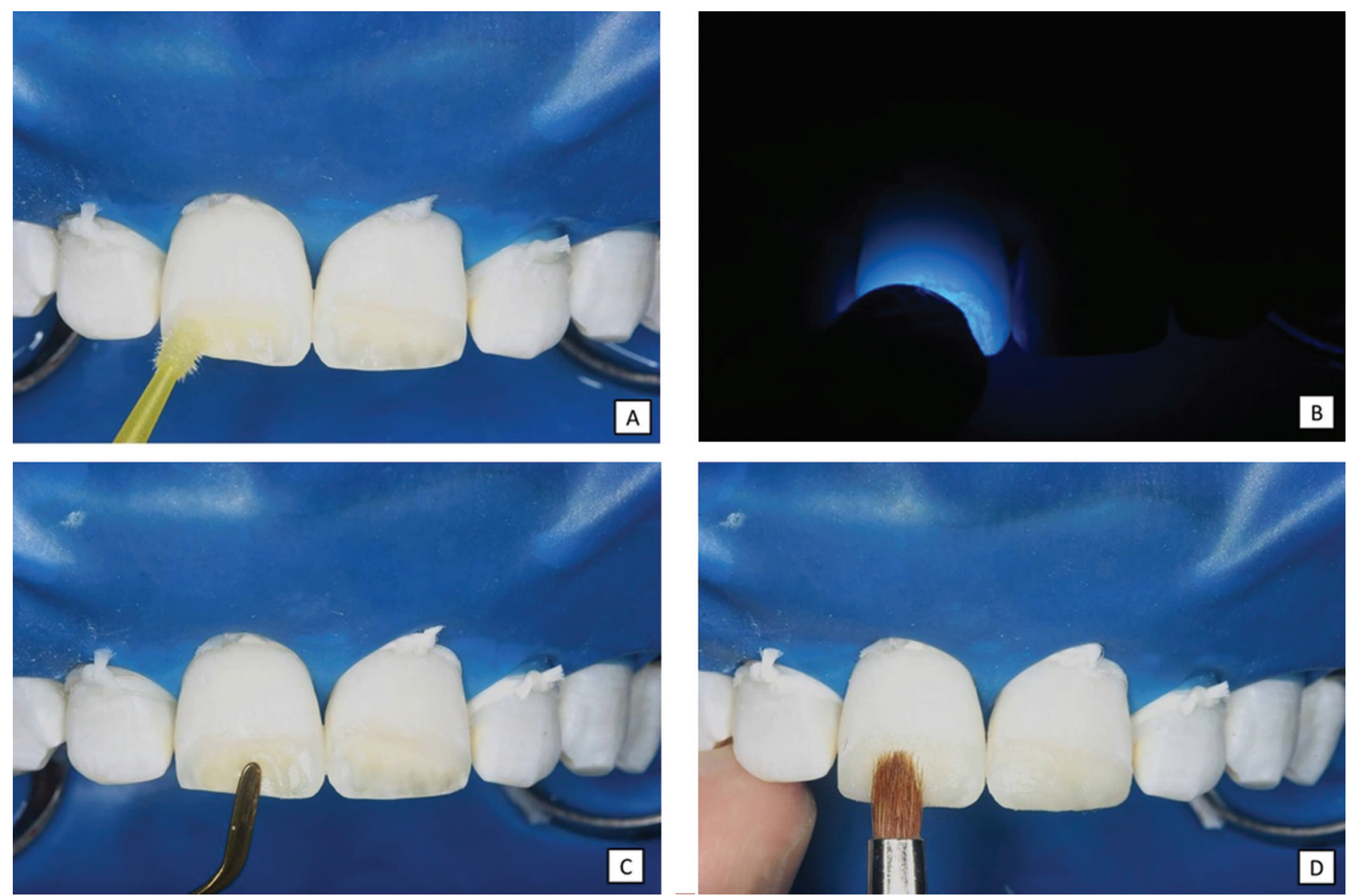

Figure 3. A) Application of adhesive system Prime Bond 2.1. B) After the solvent had evaporated, light curing was applied for 20 seconds (steps 3 A and $3 B$ repeated). C) Incremental insertion of composite resin and curing. D) Texturing the final surface layer of composite resin with a brush.

factors and patient's expectations. For clinical success in aesthetic and functional terms, the proper evaluation of the remaining tooth substrate and the careful restorative technique were crucial in re-establishing the aesthetics of the smile and immediate restoration of the patient's well-being.
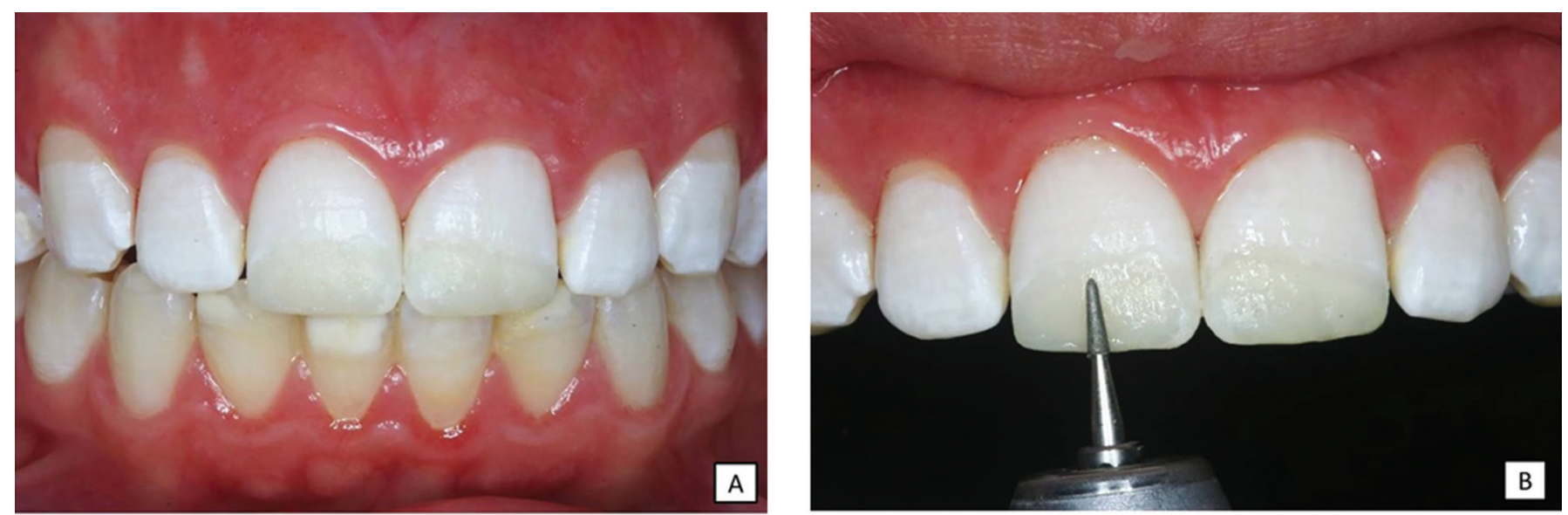

Figure 4. A) View immediately after removing absolute isolation. B) Initial finishing with diamond bur F. 

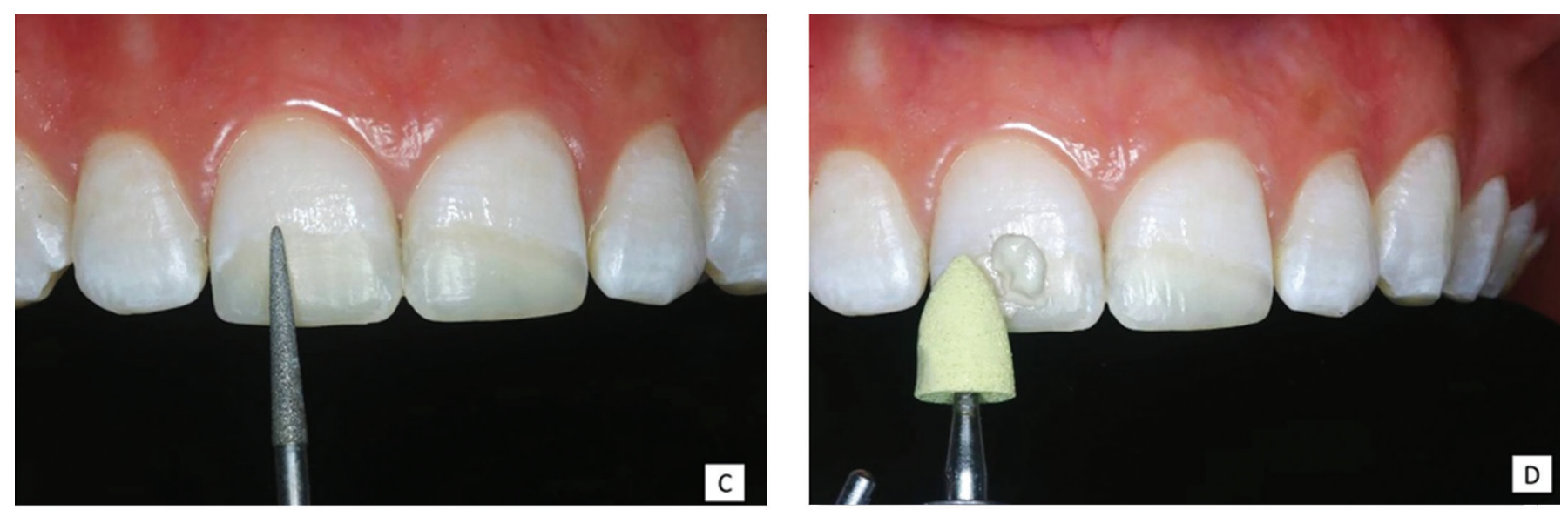

Figure 4. C) 2nd session, finishing with diamond bur F/F. D) Initial polishing with yellow rubber cup (thicker granulate).
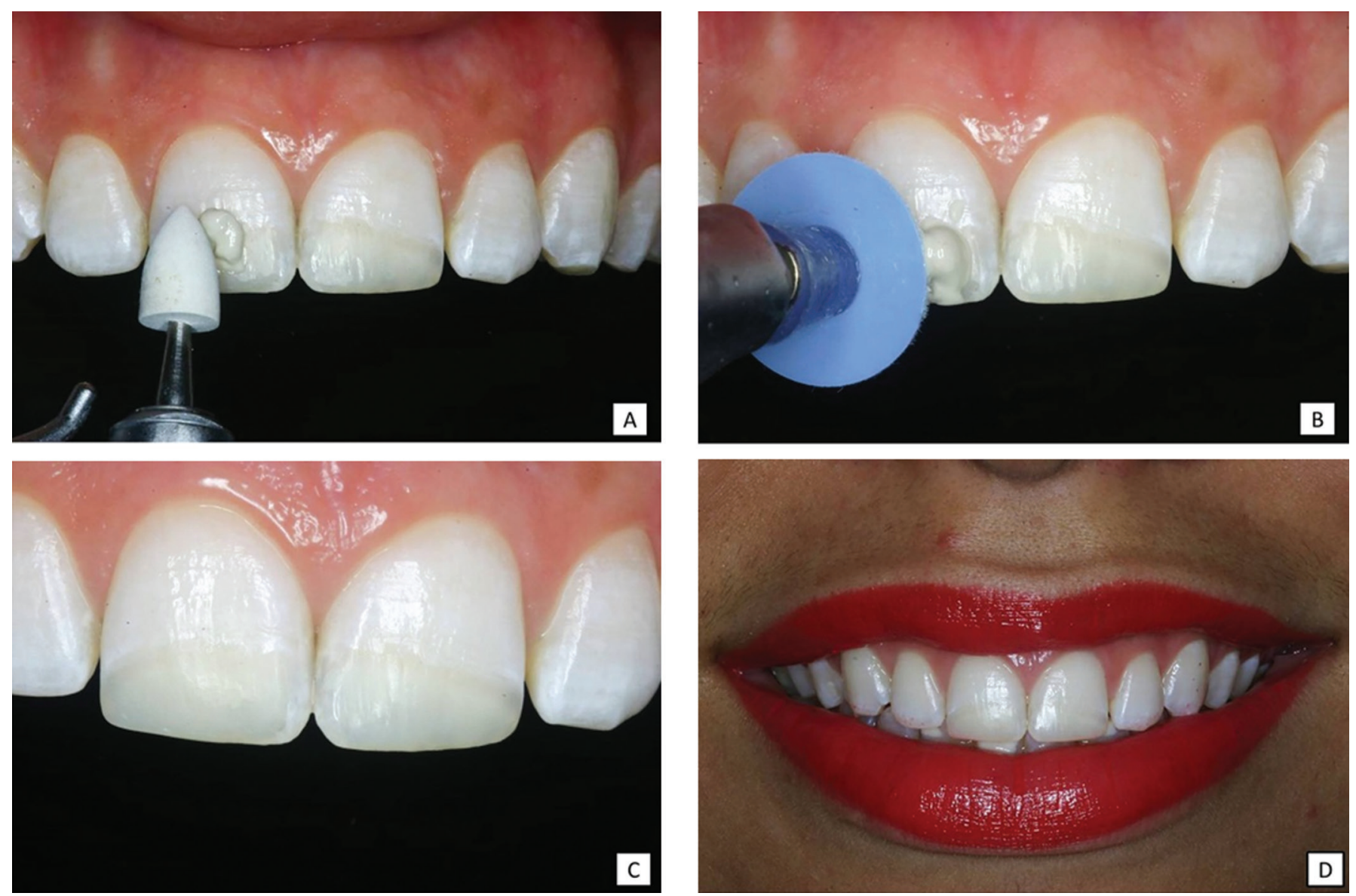

Figure 5. A) Initial polishing with white rubber cup (finer granulate). B) Final polishing with felt disc and diamond paste. C) Case finalized immediately after finishing and polishing. D) Clinical case after 7 (seven) days.

\section{Collaborators}

MF SILVA-JUNIOR was responsible for the clinical part of the case, and writing the article. RIF ASSIS was responsible for digitization of the images and writing the article. FB PAZINATTO was responsible photography and digitization of the images and guidance of the work and writing the article. 


\section{REFERENCES}

1. Ardu S, Duc O, Krejci I, Perroud R. Amelogenesis imperfecta: a conservative and progressive adhesive treatment concept. Oper Dent. 2013;38(3):235-41. doi: 10.2341/11-437-S

2. FDI Comisssion on Oral Health, Research and Epidemiology. An epidemi-ological index of developmental defects of dental enamel (DDE Index). Int Dent J. 1982;32(2):159-67.

3. Suclking GW. Developmental defects of enamelhistorical and present day perspectives of their pathogenesis. Adv Dent Res. 1989;3(2):87-94.

4. Weerheijm KL. Molar incisor hypomineralization (MIH). Eur J Paediatr Dent. 2003;4(3):115-20.

5. Weerhijm KL, Jalevick B, Alaluusua S. Molarlncisor hypomineralization. Caries Res. 2001;35:390-1.

6. Weerheijm KL. Molar incisor hypomineralization (MIH): clinical presenta-tion aetiology and management. Dent Update. 2004;31(1):9-12.

7. Bevilacqua FM, Sacramento T, Felício CM. Amelogênese imperfeita, hipoplasia de esmalte e fluorose dental: revisão da literatura. Rev UNIARA. 2010;13(2):136-48.

8. William $V$, Messer LB, Burrow MF. Molar incisor hypomineralization: review and recommendations for clinical management. Pediatr Dent. 2006;28(3):224-32.

9. Souza JB, Rodrigues PCF, Lopes LG, Guilherme AS, Freitas GC, Moreira FCL. Hipoplasia do esmalte: tratamento restaurador estético. ROBRAC. 2009;18(47):14-9.

10. Bendo CB, Scarpelli AC, Novaes-Júnior JB, Vale MPP, Paiva SM, Podeus IA. Hipoplasia de esmalte em incisivos permanentes: um acompanhamento de 6 meses. RGO, Rev Gaúch Odontol. 2007;55(1):107-12.

11. Lygidakis NA, Wong $F$, Jälevik B, Vierrou AM, Alaluusua $S$, Espelid I. Best clinical practice guidance for clinicians dealing with children presenting with molar-incisor-hypomineralisation (MIH). Eur Arch Paediatr Dent. 2010;11(2):75-81.

12. Augusto L, Quaglio JM, Pedro ACB, Silvestre FDO, Imparato JCP, Pinheiro SL. Amelogênese imperfeita. RGO, Rev Gaúch Odontol. 2005;53(3):251-4

13. Lygidakis NA. Treatment modalities in children with teeth affected by mo-lar-incisor enamel hypomineralisation (MIH): a systematic review. Eur Arch Paediatr Dent. 2010;11(2):65-74.

14. Soares CJ, Fonseca RB, Martins LR, Giannini M. Esthetic rehabilitation of anterior teeth affected by enamel hypoplasia: a case report. J Esthet Restor Dent. 2002;14(6):340-8.

15. Gomes AC, Neves LT, Gomide MR. Enamel defects in maxillary central incisors of infants with unilateral cleft lip. Cleft PalateCraniofac J. 2009;46(4):420-4.

16. Sönmez IS, Aras S, Tunç ES, Küçükesmen C. Clinical success of deproteinization in hypocalcified amelogenesis imperfecta. Quintessence Int. 2009;40(2):113-8.

17. Sabatini C, Guzmán-Armstrong S. A conservative treatment for amelogenesis imperfecta with direct resin composite restorations: a case report. J Esthet Restor Dent. 2009;21(3):161-9. 